\title{
APPLICATION OF HIRA AND SPAR-H METHOD TO CONTROL WORK ACCIDENT
}

\author{
CINDY BEAUTY SIJABAT* DAN SUNDAY NOYA \\ Industrial Engineering Study Program, Faculty of Science and Technology, Universitas Ma Chung \\ Villa Puncak Tidar N-01, Malang, East Java 65151 \\ E-mail: cindybsijabat@gmail.com
}

\begin{abstract}
ABSTRAK
Terjadinya kecelakaan di industri merupakan salah satu penyebab gangguan atau penghentian kegiatan industri. Kecelakaan kerja adalah sesuatu yang harus dihindari karena akan mengakibatkan kerugian bagi perusahaan. PT " $X$ ” adalah industri tembakau yang memiliki tingkat kecelakaan kerja cukup tinggi, oleh karena itu diperlukan tindakan untuk menghindari atau meminimalkan terjadinya kecelakaan. Hazard Identification and Risk Analysis (HIRA) adalah metode yang bertujuan untuk mengidentifikasi semua jenis bahaya yang terkandung dalam kegiatan kerja. Sedangkan metode Standardized Plant Analysis Risk Human Reliability Assessment (SPAR-H) adalah sebuah metode yang bertujuan untuk mengetahui kemungkinan terjadinya kesalahan manusia ketika melakukan aktivitas kerja. Dari penelitian yang telah dilakukan, disimpulkan bahwa terjadinya kecelakaan di tempat kerja PT " $X$ " disebabkan oleh adanya kondisi lingkungan dan tindakan pekerja yang tidak aman serta ketidaksesuaian dengan undang-undang K3. PT " $X$ ” perlu melakukan beberapa tindakan korektif sehingga kecelakaan dapat diminimalkan. Dalam studi tersebut, $P T$ " $X$ ” perlu membuat perbaikan melalui tindakan administrasi dan penggunaan peralatan perlindungan.
\end{abstract}

Kata kunci: kecelakaan kerja, HIRA, SPAR-H

\begin{abstract}
The accident occurred in industry is one of the causes of work disruption or cessation. Work accident should be avoided because of causing risk for company. $P T$ " $X$ " is a tobacco company which has a high level of work accident. Therefore, it is necessary to establish a particular effort in order to prevent and reduce the accident. Hazard Identification and Risk Analysis (HIRA) is the method aims to identify any risk types included in the work operation. Where as Standardized Plant Analysis Risk Human Reliability Assessment (SPAR-H) is the method aims to find out the possibility of human error occurrence in the work operations. Based on the research conducted, it can be concluded that the accident occurred in PT. "X" is caused by environmental condition and insecure workers' action, and inappropriateness with HSE procedures. PT " $X$ " should enroll some corrective actions so the accident can be reduced. In this study, $P T$ " $X$ " should create improvement through administrative action and the use of safety equipment.
\end{abstract}

Key words: work accident, HIRA, SPAR-H

\section{INTRODUCTION}

In order to achieve improvement in the field of industry, labors (human resources) have a very important role. Therefore the achievement of safety and occupational health is the very basic needs. Accident occurred in an industry is one of causes of the work disruption or cessation. However, in general problem of safety and

* Penulis korespondensi occupational health (K3) in Indonesia are still often neglected, it is proved by the high number of accidents in Indonesia. More than 15,000 largescale companies in Indonesia, recently just $2.1 \%$ of them have implemented the HSE management system. Safety hazards can be caused from a variety of activities or from the use of equipment and machinery. There are many different kinds 
of dangers included in a work activity and every kind of danger can arise from a variety of different sources. The type of hazards that commonly occurred in the industrial field can be classified into four categories, namely mechanical hazards, physical hazards, chemical hazards, and hazards of work design (Suhardi, 2008).

While, the cause of work accident can be divided into two parts, those are unsafe action and unsafe condition. To prevent and reduce risks that may arise in performing work activities, it should be overcome by an effort. The foremost thing to do in order to control work accident is by identifying hazards. Hazard Identification and Risk Assessment (HIRA) is one of the methods used to identify hazards in a work activity. The analysis of the unsafe action can be performed by using SPAR-H. SPAR-H method is used to measure human reliability assessment in performing work activities. To perform an analysis of the causes of the unsafe condition, ergonomics rule is adjusted.

PT " $\mathrm{X}$ " is Green Leaf Threshing (GLT) tobacco producer that has a fairly high level of work accidents. The research will cover the identification of the hazards by using methods of HIRA in any work activities which are examined in each division. Next, using method of SPAR$\mathrm{H}$ and the suitability of the environment with respect to the rules of workplace safety and health (K3) are the recommendation which can be proposed as the improvements for minimizing the work accident in PT " $\mathrm{X}$ ".

\section{METHODS}

Research conducted over the past two months from January to February 2014. The research is carried out in the tobacco-producing company GLT (green leaf threshing) and according to the stage as follows:

\section{Preliminary Observation}

The initial stage is the stage of research that aims to find out the condition of the company, so that, the problems that occurred in the company can be identified. The step carried out in the initial observation phase is conducting interview to production manager, quality control manager, and some of the company staff.

\section{Data Collection}

After the formulation of the problem, the next section is to collect the data that is related to the problem issues. The types of data used in this research is the primary data in the form of observations and interviews, secondary data as well as data in the form of a work accident company, work procedures, and literature review that is related to the research.

\section{Data Processing Method}

The primary and secondary data obtained are processed further to achieve the research objectives that have been determined. The stages of data processing which are performed in this research are as follows:

\section{Hazard analysis by HIRA Method}

Hazard identification is a systematic effort to identify all the situations or incidents that could potentially cause accidents which may arise in the workplace. The identification of hazards should be understood in advance such as the source of current danger in the work environment, and factors from the danger impact as well as the mechanism of accidents that may arise (Kumar and Kumar, 2012). Hazard Identification and Risk Analysis is one of the types of method used for hazard identification process. The information obtained from the identification and descriptions by using HIRA are their respective work activities, the causes of hazards, and hazard classification as well as the impact of hazards.

HIRA is closely related to risk assessment and one of the risk assessment phases is conducted by identifying hazards. The steps in the first stage begin respectively with description of each activity of the work scrutinized, risk analysis that can be inflicted by their respective work activities, and analysis of hazard impact. After analyzing danger impacts, determining the level of effect and frequency as well as the danger risks can 
be obtained from the risk assessment (Raj and Shivasankaran, 2014).

Work operations that are observed in this research are the activities at the receiving division, process division, and quality control division. The evaluation is performed using the worksheet HIRA in accordance with the results obtained through observation. HIRA worksheet used in this research is in Table 1:

\section{Risk Assessment}

Risk is the possibility of harm and the work accident occurrence in a cycle of certain operations. Risk management is an act comprehensively planned, structured, and to prevent the occurrence of accidents. Risk assessment is an activity that aims to quantify the magnitude of a risk so it can be known whether the risks are acceptable or not and do a proper repair. Risk assessment

Table 1. Hazard Identification in Processing-Blending

\begin{tabular}{cllll}
\hline Area & \multicolumn{1}{c}{ Step } & \multicolumn{1}{c}{ Activity } & \multicolumn{1}{c}{ Failure Description } & Consequence \\
\hline Receiving & 0 & $\begin{array}{l}\text { Receiving raw } \\
\text { materials }\end{array}$ & & \\
& 1 & $\begin{array}{l}\text { Moving raw } \\
\text { materials from } \\
\text { truck to forklift } \\
\text { Receiving raw } \\
\text { materials }\end{array}$ & $\begin{array}{l}\text { Inappropriate position that } \\
\text { doesn't match the manual lifting }\end{array}$ & $\begin{array}{l}\text { Direct contact with the raw } \\
\text { materials that can cause allergies }\end{array}$ \\
& & & Falling from a \\
height & Allergic \\
\hline
\end{tabular}

Table 2. Likelihood Criteria

\begin{tabular}{|c|c|c|c|}
\hline \multicolumn{4}{|c|}{ Likelihood } \\
\hline \multirow{2}{*}{ Level } & \multirow{2}{*}{ Criteria } & \multicolumn{2}{|l|}{ Description } \\
\hline & & Qualitative & Quantitative \\
\hline 1 & Rare & $\begin{array}{l}\text { Can contemplate but not only when the state of } \\
\text { being extreme }\end{array}$ & Less than 1 times per 10 years \\
\hline 2 & Unlikely & $\begin{array}{l}\text { Has not occurred but could appear/happen at a } \\
\text { time }\end{array}$ & Occurring 1 times yearly \\
\hline 3 & Perhaps & $\begin{array}{l}\text { Should have happened and might have } \\
\text { happened/comes up here or elsewhere }\end{array}$ & $\begin{array}{l}1 \text { time per } 5 \text { years up to } 1 \text { time } \\
\text { per year }\end{array}$ \\
\hline 4 & Most likely & $\begin{array}{l}\text { Can happen easily, may appear in most } \\
\text { circumstances occur }\end{array}$ & $\begin{array}{l}\text { More than } 1 \text { time per year to } \\
1 \text { time per month }\end{array}$ \\
\hline
\end{tabular}

Table 3. Consequences/Severity

\begin{tabular}{|c|c|c|c|}
\hline \multicolumn{4}{|c|}{ Consequences / Severity } \\
\hline Level & Description & Severity & Working Days \\
\hline 1 & Insignificant & $\begin{array}{l}\text { The incident caused no loss or injury in } \\
\text { humans }\end{array}$ & Does not cause lost work days \\
\hline 2 & Minor & $\begin{array}{l}\text { Give rise to minor injuries, losses small, } \\
\text { and do not cause serious impact to business } \\
\text { continuity }\end{array}$ & $\begin{array}{l}\text { Can still working on the same } \\
\text { shift }\end{array}$ \\
\hline 3 & Moderate & $\begin{array}{l}\text { Injuries and hospitalized, did not cause } \\
\text { permanent disability, moderate financial } \\
\text { losses }\end{array}$ & Lost work day under 3 days \\
\hline 4 & Severe & $\begin{array}{l}\text { Cause severe injury, permanent disability, } \\
\text { financial losses and pose a serious impact on } \\
\text { business continuity }\end{array}$ & $\begin{array}{l}\text { Working days lost three days } \\
\text { or more }\end{array}$ \\
\hline 5 & Disaster & $\begin{array}{l}\text { Resulted in the deaths and severe losses, } \\
\text { it can even stop the business activities of } \\
\text { forever }\end{array}$ & Lost work days are forever \\
\hline
\end{tabular}


Table 4. Risk Level

\begin{tabular}{lcccccc}
\hline Risk Level & \multicolumn{1}{c}{} \\
\hline \multirow{3}{*}{ Likelihood } & $\mathbf{5}$ & $\mathbf{5}$ & $\mathbf{1 0}$ & $\mathbf{1 5}$ & $\mathbf{2 0}$ & $\mathbf{2 5}$ \\
& $\mathbf{4}$ & 4 & $\mathbf{8}$ & $\mathbf{1 2}$ & $\mathbf{1 6}$ & $\mathbf{2 0}$ \\
& $\mathbf{3}$ & $\mathbf{3}$ & $\mathbf{6}$ & $\mathbf{9}$ & $\mathbf{1 2}$ & $\mathbf{1 5}$ \\
& $\mathbf{2}$ & $\mathbf{2}$ & $\mathbf{4}$ & $\mathbf{6}$ & $\mathbf{8}$ & $\mathbf{1 0}$ \\
& $\mathbf{1}$ & $\mathbf{1}$ & $\mathbf{2}$ & $\mathbf{3}$ & $\mathbf{4}$ & $\mathbf{5}$ \\
\hline \multirow{3}{*}{ Scale } & \multicolumn{1}{c}{$\mathbf{2}$} & $\mathbf{3}$ & $\mathbf{4}$ & $\mathbf{5}$ \\
& & \multicolumn{5}{c}{ Severity }
\end{tabular}

The following is a description of the risk matrix:

1. yellow = low risk Area

2. dark blue = medium risk

3. red $=$ high risk areas

4. light blue = extreme risk

can be performed based on criteria of frequency of occurrence (likelihood) and consequence (severity).

Rating criteria for likelihood and severity can be seen in the Table 2 and 3 respectively (Rachim, 2014).

Risk rating can be determined for the work activities as well as a source of danger which is shown in the following risk matrix shown in Table 4 (Rachim, 2014): Then, the assessment of risks of work accidents as data input will be processed by using method of HIRA. The assessment is done based on criteria of likelihood (frequencies occurs) and severity (consequences). Based on the obtained values, risk levels can be found in the respective work accident. The level of risk will also show the impact of work accidents in the company. Next, through the value criterion of likelihood and severity obtained, value of the risk of a work activity as well as a source of danger which is indicated on the matrix of risks can be determined.

Table 5. Performance Shaping Factor (PSF)

\begin{tabular}{|c|c|c|}
\hline SPAR-H PSF's & SPAR-H PSF Levels & SPAR-H Multipliers \\
\hline \multirow{5}{*}{ Available Time } & Inadequate Time & $\mathrm{P}$ Failure $=1.0$ \\
\hline & Time Available $=$ Time Required & 10 \\
\hline & Nominal Time & 1 \\
\hline & Time Available $\geq 5 \times$ Time Required & 0.1 \\
\hline & Time Available $\geq 50 \times$ Time Required & 0.001 \\
\hline \multirow{3}{*}{ Stress/Stressors } & Extreme & 5 \\
\hline & High & 2 \\
\hline & Nominal & 1 \\
\hline \multirow{3}{*}{ Complexity } & Highly Complex & 5 \\
\hline & Moderately Complex & 2 \\
\hline & Nominal & 1 \\
\hline \multirow{3}{*}{$\begin{array}{l}\text { Experience/ } \\
\text { Training }\end{array}$} & Low & 3 \\
\hline & Nominal & 1 \\
\hline & High & 0.5 \\
\hline \multirow{3}{*}{ Procedures } & Not Available & 50 \\
\hline & Incomplete & 20 \\
\hline & Available, but poor & 5 \\
\hline \multirow{4}{*}{ Ergonomics } & Missing/ Misleading & 50 \\
\hline & Poor & 10 \\
\hline & Nominal & 1 \\
\hline & Good & 0.5 \\
\hline \multirow{3}{*}{ Fitness for Duty } & Unfit & $\mathrm{P}$ Failure $=1.0$ \\
\hline & Degrade Fitness & 5 \\
\hline & Nominal & 1 \\
\hline \multirow{3}{*}{ Work Process } & Poor & 2 \\
\hline & Nominal & 1 \\
\hline & Good & 0.8 \\
\hline
\end{tabular}




\section{Identification of Work Accident}

Work accident is an unexpected event that occurs without intention or plan, where such events always cause any harm and hinder the work activities. Cause of the accident can be classified into several categories, namely the lack of control systems, basic causes (human factors, and employment), and the direct cause (unsafe act and unsafe condition). At this time, research will be carried out an analysis of the direct cause. The unsafe conditions are hazardous conditions and circumstances that directly provide opportunities to work accident. Cause of the accident at this research is classified into two parts, namely work accident caused by unsafe action that will be identified by using the method of SPAR-H and accidents caused by unsafe condition that will be identified using the rules of ergonomics and the HSE legislation.

In SPAR-H method, level of human error are expressed in index HEP (human error probabilities). The index HEP obtained based on the value of PSF's (performance shaping factors). The aspects that taken into account in determining the value of PSF using SPAR-H is: available time, stress, experience and training, complexity, ergonomics, procedure, fitness for duty, and the work process. All aspects have same priority. Categories of assessment for each aspect is summarized in Table 5 (Farid, 2012).

The PSF's value is used for calculating the value of HEP to indicate the level of human error in a work activity. Value of failure probability used for diagnose the activities is 0.01 . The action value of failure probability used is 0.001 . The formula used to get the value of HEP is as follows (Syamsidi, 2014):

HEP $=$ failure probabilities $\mathrm{x}$ time $\mathrm{x}$ stress $\mathrm{x}$ complexity $\mathrm{x}$ experience $\mathrm{x}$ procedures $\mathrm{x}$ ergonomics $\mathrm{x}$ fitness for duty $\mathrm{x}$ processors

When there are three or more PSF'S which are negative or worse than nominal conditions, then to calculate the HEP, the following formula is used:

$$
\mathrm{HEP}=\frac{\mathrm{NHSP} \times \text { PSF composite }}{\mathrm{NHSP} \times(\mathrm{PSF} \text { composite }-1)+1}
$$

\section{Determining PSF's Level}

1. Available Time

In this research, available time will be classified into PSF's level (Table 4) with the background as follows:

- Inadequate time, the operators can't accomplish the job in the time where management has provided.

- Available time is equal to the required time, no time left for workers to do other activities besides work activity.

- Nominal time, the available time is longer than the minimum time required by workers to finish the work.

- Available time $>5 \times$ time required, the ratio between time provided and actual time spent workers to finish activity is 5:1.

- Available time $>50 \times$ time required, the ratio between time provided and actual time spent workers to finish activity is 50:1

- Insufficient information, there is no sufficient information to determine the level of available time.

2. Stress

In this research, stress will be classified into PSF's level (Table 4) with the following background:

- Extreme, the performance of workers falls drastically because of stress.

- High, the workers need to be focused and be concentered, but not causing the performance of workers to be down.

- Nominal, causal stress factor which can be overcome by workers.

- Insufficient information, there is no sufficient information to determine the level of stress.

3. Complexity

In this research, complexity will be classified into PSF's level (Table 4) in view of the main following considerations:

- Highly complex, need high skill (ability).

- Moderately complex, there are some variables and ambiguities involved in carrying out the work activity. 
- Nominal, there are few kinds of variable that involved in carrying out the work activity.

- Insufficient information, there is no sufficient information to determine the level of complexity.

- Obvious diagnosis, the diagnose activity is very simple and easy to analyzed.

4. Experience and Training

In this research, experience and training will be classified into PSF's level (Table 4) with reasons as follows:

- Low, the experience of workers and training that followed by workers less than six months.

- Nominal, workers have experience in doing the duty more than six months.

- High, worker has had extensive experience.

- Insufficient information, there is no sufficient information to determine the level of experience and training.

5. Procedures

In this research, procedures will be classified into PSF's level (Table 4) in view of the main following considerations:

- Not available, there is no procedure for worker in establishing work activity.

- Incomplete, the procedure is available, but information required in carrying out work activity is not included in that procedure.

- Available but poor, the procedure is difficult to understand, there are ambiguities, not consistent, and the format is not appropriate.

- Nominal, the procedure can be used in carrying out the work activity.

- Diagnostic/symptom oriented, the procedure required in diagnose activity is available.

- Insufficient information, there is no sufficient information to determine the level of procedures

6. Ergonomics

In this research, ergonomics will be classified into PSF's level (Table 4) in view of the main following considerations:

- Poor, work design and other (ergonomic) aspects is not applicable and brings negative impacts to the workers.
- Nominal, the design of ergonomic aspects doesn't ease the workers in carrying out the work activity.

- Good, the design of ergonomic aspects facilitate workers in carrying out work activity.

- Insufficient information, there is no sufficient information to determine the level of ergonomics.

7. Fitness for duty

In this research, fitness for duty will be classified into PSF's level (Table 4) with respect to the following consideration:

- Unfit, the workers was sick before conducting the job and keep on working.

- Degraded fitness, the health condition of workers start to be disrupted when conducting the job.

- Nominal, the health condition of workers is undisturbed before and when conducting the job.

- Insufficient information, there is no sufficient information to determine the level of fitness for duty.

8. Work Processes

In this research, work processes will be classified into PSF's level (Table 4) with respect to the following consideration:

- Poor, the communication between workers and the command from superior is not clear.

- Nominal, the information and communication give no effect on the performance of work activity.

- Good, there is good communication between the workers.

- Insufficient information, there is no sufficient information to determine the level of work processes.

\section{Result Analysis}

In this stage, the value of SPAR-H obtained will be compared with the existing condition of the company. It is intend to evaluate work accident and all the things that are not appropriate with the prevailing regulations and rules of workplace safety and health (K3).

\section{Recommendation to Improvement}

Work accidents and hazards can be controlled by using several ways, including: 
elimination, substitution, isolation, minimization, administration, and safety equipment (APD). Elimination is an effort to modify or remove the material or process, so that the danger can be eliminated. Substitution is an effort to replace the materials that have a high degree of risk, with the materials that have a lower degree of risk. Minimization is an effort to lower the level of risk in a manner of minimizing the use and storage of dangerous materials or substances. This effort attempts to separate the isolation source of danger from humans (Kurniawati, 2014). The administrative effort is an attempt to control hazards through creating procedures and instructions. The use of safety equipment (APD) is an effort that aims to protect workers from hazards. Through analysis of the obtained results, then the proposed improvement can be proposed to the company to minimize the work accident rate.

\section{Conclusions and Recommendations}

The final stage of the research is conclude the overall objectives and give some suggestions. The conclusion will answer research objectives that have been determined in the beginning, while the suggestions are addressed for further research.

\section{RESULTS AND DISCUSSION}

\section{Hazard Analysis by HIRA Method}

At this time, analysis is focused on the work activities in the division of receiving, processing, and quality control. The result of the hazards identification in one of the processing division's work activities is shown in Table 6.

There are 17 work activities observed in order to explore hazard which may occurred, where each individual work activity is elaborated upon their respective stages.

\section{Risk Assessment}

After identifying hazards, risk assessment is performed for each work activity in further stage. An example of risk assessment result of work activity in processing Division is shown in Table 7.

There are 57 appraised work activities in three different divisions. Based on the risk assessment

Table 6. Processing-Blending Hazard Analysis

\begin{tabular}{|c|c|c|c|}
\hline Step & Activity & Failure Description & Consequence \\
\hline 0 & Blending & & \\
\hline 1 & Opening the box of raw materials & Scratched by sharp objects & Laceration \\
\hline 2 & $\begin{array}{l}\text { Moving the box of raw materials } \\
\text { to the blending process }\end{array}$ & $\begin{array}{l}\text { Inappropriate position that doesn't } \\
\text { macth the manual lifting }\end{array}$ & Muscle injury \\
\hline 3 & $\begin{array}{l}\text { Taking the non tobacco raw } \\
\text { material }\end{array}$ & Injured by sharp NTRM & Laceration \\
\hline 4 & $\begin{array}{l}\text { Arranging raw materials in } \\
\text { accordance with the composition } \\
\text { of feeding table specified }\end{array}$ & $\begin{array}{l}\text { - Direct contact with raw materials } \\
\text { - Inhaling the aroma of tobacco }\end{array}$ & $\begin{array}{ll}\text { - } & \text { Alergic } \\
\text { - } & \text { Dizzy }\end{array}$ \\
\hline
\end{tabular}

Table 7. Processing-Blending Risk Assessment

\begin{tabular}{|c|c|c|c|c|}
\hline \multirow{2}{*}{ Step } & \multirow{2}{*}{ Activity } & \multicolumn{2}{|c|}{ Risk Assessment } & \multirow{2}{*}{ Rank of Risk } \\
\hline & & Likelihood & Severity & \\
\hline 0 & Blending & & & \\
\hline 1 & Opening the box of raw materials & 5 & 2 & high risk \\
\hline 2 & $\begin{array}{l}\text { Moving the box of raw materials to the } \\
\text { blending process }\end{array}$ & 4 & 2 & high risk \\
\hline 3 & Taking the Non Tobacco Raw Material & 4 & 2 & high risk \\
\hline 4 & $\begin{array}{l}\text { Arranging raw materials in accordance with } \\
\text { the composition of feeding table specified }\end{array}$ & 4 & 2 & high risk \\
\hline
\end{tabular}


Table 8. Processing-Blending HEP Calculation

\begin{tabular}{lcccc}
\hline \multicolumn{1}{c}{ Factors } & \multicolumn{4}{c}{ Task Step } \\
\cline { 2 - 5 } Multiplier & $\mathbf{1}$ & $\mathbf{2}$ & $\mathbf{3}$ & $\mathbf{4}$ \\
\hline Available & 0.1 & 0,1 & 1 & 1 \\
Time & & & & \\
Stress & 1 & 1 & 2 & 1 \\
Complexity & 1 & 1 & 2 & 1 \\
Experience & 1 & 1 & 1 & 1 \\
$\begin{array}{l}\text { Procedure } \\
\text { Ergonomics }\end{array}$ & 50 & 50 & 1 & 1 \\
Fitness for & 1 & 1 & 1 & 1 \\
$\begin{array}{l}\text { Duty } \\
\text { Work }\end{array}$ & 1 & 1 & 2 & 1 \\
Process & & & & \\
PSF & 5 & 5 & 8 & 1 \\
Composite & & & & \\
NHEP & 0.001 & 0.001 & 0.001 & 0.001 \\
HEP & 0.005 & 0.005 & 0.0075 & 0.001 \\
\hline
\end{tabular}

using Table 7, it can be found that there are 3 risk levels corresponding to work activity which are 32 at high risk, 15 at moderate risk, and 7 at low risk. The assessment of likelihood and severity criteria is based on company's actual work accident data.

\section{HEP Calculation}

Next, we should calculate human error probabilities (HEP) by using SPAR-H method so that it can be known how big the influence of human error with respect to the occurrence of accidents in each work activity. An example of the calculation of the value of HEP in work activities in the processing Division is summarized in Table 8.

Based on calculation by using SPAR-H method obtained that HEP high i.e. of 0.29 activities occur on taking samples ordering the $2^{\text {nd }}$ stage. The 2 nd highest HEP value is found in the cleaning engine cylinder activity with worth index 0.23 . The $3^{\text {rd }}$ and $4^{\text {th }}$ highest HEP values are found in phase 2 and 3 of surveillance activities at drying process with worth index 0.2 . The $5^{\text {th }}$ highest HEP value is retrieved in drying process as supervisory activity of the $5^{\text {th }}$ stage with worth index 0.1 . It indicates that the value for the fifth such work activities, human error contributes a high enough in the cause of accidents of work.

Whereas the lowest HEP obtained through measurements of the SPAR-H occurred in some work activities, namely receiving at the $2^{\text {nd }}$ stage with HEP 0,00005, moisture content test at $3^{\text {rd }}$ and $4^{\text {th }}$ phase activities as well as test the $3^{\text {rd }}$ stage of NTRM have same value i.e. $0.0005 \mathrm{HEP}$, take samples ordering phase of activity 1 and activity processing-blending stage 4 with a value of 0.001 , and HEP activities stem test the $3^{\text {rd }}$ phase tester with HEP values of 0.001 . It suggests that for some activities with the lowest contribution, HEP human error causing the occurrence of accidents is small enough.

\section{Analysis of The Environmental Work Accidents}

If look at the environment, there are several factors that cause accidents, working on safety equipment used by workers for protection in $\mathrm{PT}$ " $\mathrm{X}$ " is not sufficient. Company just provides protection several tools needed such as earplug, self-white-eye, and safety shoes. A self protection provided by the company until now is only about mitts and masks, but the mask used is not conforming to standard whereas the proper mask should be thin and obstruct dust to be inhaled by workers. The environmental work in PT "X" is rated dealing ergonomic by using factors such as no dusty air, no dusty exhaust system which constructed systematically. In addition, the temperature of the environmental work is quite high so it causes to uncomfortably work.

PT "X" does not have yet commitment and the supervision of a good and systematic rules of workplace safety and health (K3), where training and education programs about the $\mathrm{K} 3$ for employees is still very limited. This leads many workers who do not understand the dangers to work accident. The absence of clear rules and sanctions to violations of occupational health and safety becomes no matter for the workers and work accidents are constantly repeating. 


\section{Recommendation of Improvement}

Based on the results of risk identification, analysis, and measurement reliability $\mathrm{K} 3$ workers, the action will be recommended to reduce and prevent the occurrence of accidents. Work accident is identified in this research and classified into 14 kinds of work accident: muscle injuries, allergy, forklift, hit by objects, scratch injury, conveyor accidents, falling from a height, dizziness, slip, dust-exposed, noise-exposed, banged, being exposed to high temperature, injured by machine, burned. Corrective action recommendations are given based on the type of accident that happened.

The given recommendations to reduce and prevent the occurrence of muscles injuries is by providing knowledge about how to operate well manual lifting, as well as providing additional tools in the form of working clothe such as body appendages that can withstand the hips and waist. The given recommendation to reduce and prevent the occurrence of allergies is by giving self protection tools such as gloves to the workers Recommendations are given to reduce the risk of work accidents are: provide a clear path of forklifts and gives signs that must be adhered to pedestrians on the impassable area of forklift, establish health screening to forklift drivers on a routine basis, provide training with a period of time to all drivers of forklift.

Recommendations given to reduce conveyor accidents are by providing dangerous signs on jammed conveyor and providing knowledge about the dangers of work accident on dangerous conveyor areas so that workers are more vigilant in doing their job. Recommendations given to reduce dust-exposed are: provide proper self-protection in the form of a standard mask which can hinder the dust to get into the respiratory system, providing protective equipment, including safety glasses so that workers can carry out work activities, create signs prohibiting the other workers to get through the area while being cleaned, and providing dust suction system, where the dust will be automatically discarded and smoked out the factory. With respect to other types of work accident, recommendations are given based on the type of work accident and the condition that causes accident.

\section{CONCLUSION}

Based on the research that has been done, it is known that the whole work activities in receiving division, processing division, and quality control division in PT " $\mathrm{X}$ " contain some dangers causing accidents, ranging from high risk to low risk. Through the identification and analysis of the results, it can be concluded that the accident happened in the workplace PT " $\mathrm{X}$ " is caused by human error and environmental conditions that are not ergonomic. To minimize work accidents happened, some recommendations both administratively and the use of self-protection (APD) are proposed. Administrative improvement can be done by making a good and clear work procedure, and give training periodically. Besides, it is necessary to implement regular safety caution to cultivate employee's concern in occupational safety.

\section{REFERENCE}

Farid, A.K., 2012. Reliability Assessment sebagai Upaya Pengurangan Human Error dalam Penerapan Kesehatan dan Keselamatan Kerja, Skripsi, Program Studi Teknik Industri, Universitas Indonesia, Depok.

Idaho National Laboratory, 2005. The SPAR-H Human Reliability Analysis Method, Washington DC: U.S. Nuclear Regulatory Commission.

Kumar, M.S. dan Kumar, P.S., 2012. Hazard Identification and Risk Assessment in Foundry, IOSR Journal of Mechanical and Civil Engineering, 33-37.

Kurniawati, E., 2014. Analisis Potensi Kecelakaan Kerja Pada Departemen Produksi Springbed dengan Metode Hazard Identification nd Risk Assessment (HIRA), Jurnal Rekayasa dan Manajemen Sistem Industri, 2 (1).

Rachim, A., 2014. Analisis Potensi Bahaya Menggunakan Metode Hazard Identification Risk Assessment, Industrial Engineering Online Journal, 3 (2). 
Raj, S.G, and Shivasankaran, N., 2014. Hazard Identification and Risk Assessment in DeInking Plant, International Journal of Research in Aeronautical and Mechanical Engineering, 2 (3), 202-208.

Suhardi, B., 2008. Perancangan Sistem Kerja dan Ergonomi Industri, Jilid 2, Jakarta: Direktorat Pembinaan Sekolah Menengah Kejuruan.
Syamsidi, L.M., 2014. Analisis Tingkat Keandalan PPKA NX (Pengatur Perjalanan Kereta Api) Menggunakan Metode SPAR-H (Standardized Plant Analysis Risk-Human Reliability Analysis), Industrial Engineering Online Journal, 3 (1). 